\title{
【特 集：廃棄物問題をめぐる法制度の展開】
}

\section{産業廃棄物処理をめぐる法制度の現状と課題}

\author{
村 田哲 夫*
}

【要 旨】昭和 45 年に廃棄物処理法が制定され, 産業廃棄物の処理は事業者の責任とされた。しかし， 廃茰物処理法は，産業廃裹物の処理に問題が起るたびごとに，規制が強化されている。

最近産業廃棄物の不適正処理や不法投裹により環境の污染が惹起されるとして，住民と廃裹物処理業 者さらには行政との紛争が各地で発生している。

廃棄物処理法は，こうした問題を解決するために平成 9 年大幅な改正をみた。しかしこの改正は必ず しあ充分でなく，また新たな問題を生じさせている。資源循環型社会を構築するためには廃棄物処理と いう下流対策のための法制度ではなく, リサイクル・廃棄物処理を一体とした新たな法律案が必要であ る。その際の視点としては行政改革および地方分権である。

キーワード : 再生利用の認定の特例, 産業廃裹物処理施設の許可, マニフェスト制度, 原状回復システ 厶, 行政改革・地方分権

1.はじめに

昭和 45 年 7 月 14 日に発表された生活環境審議会の 「都市・産業廃棄物にかかる処理処分の体系及び方法に ついて」と題する答申を踏まえ, 昭和 45 年 12 月 18 日 に, 廃棄物の処理及び清挦に関する法律（廃棄物処理法 という）が制定された。この法律案の政府提案説明によ れば,「「日我が国における産業活動の拡大，国民生活 の向上等に伴って排出される各種の廃栽物は膨大な量に のぼり，その質もまた著しく変化しております。特に産 業廃裹物の多くは, 有害物質や処理の困難な物質を含み, 公害の原因となっております。」とあるように，この法 律は，それまで必ずしもその排出の実態が明らかにされ ていなかった産業廃棄物に焦点をあて, 廃棄物を一般廃 裹物之産業廃衰物に分類するととあに, 産業廃棄物につ いて事業者の処理責任を明確にした点に特徵がある1)。

この廃棄物処理法は, 辠法な処理行為に対する罰則の 強化, 事業者の処理責任体制の整備, 許可制度など産業 廃裹物処理業者の監督の強化, 産業廃棄物処理の実態把

原稿受付 1998.8 .18

* 大阪学院大学法学部 教授

連絡先： ₹ 564-0011 吹田市岸㧅南 2丁目 36-1
握と埋立地の届出などについての指導監督等を骨子とす る昭和 50 年 12 月 11 日に発表された生活環境蕃議会の 答申に基づき,この答申の趣旨に沿う改正が昭和 51 年 になされた。また平成 3 年には, 平成 2 年 12 月 10 日発 表された生活環境審議会の答申に基づき, 特別管理廃棄 物の新設, 適正処理困難物についての自己評価, 事業者 に対する計画策定指示権, 産業廃棄物処理業の許可の更 新制, 産業廃棄物処理施設の設置の許可制の導入など廃 棄物処理法の大幅な改正を行った2)。

今回の平成 9 年の廃棄物処理法の改正（今回の改正之 いう）は, 厚生省の説明によれば, 最近産業廃棄物の最 終処分場の立地が困難になってきているのは住民不信に 基づく紛争が多発していることに起因し，それに対応す ることが必要であり, また不法投棄に対する対策を講じ るという点から所要の改正が必要であるというあので あった。

このように廃裹物処理法はその制定以来事業活動に よって生じる産業廃棄物の処理を巡って主要な改正が行 われてきたといってよい。しかしながらこれまでの改正 は十分なものではなくその結果平成 9 年の改正に至った のである。本稿は, この今回の改正は産業廃棄物に関す る課題を解決したといえるのか, また法解釈の面で新た な問題が生じていないかについて, その法制度の現状を 
概観するととあに残された課題について検討しょうとす るものである。

\section{2. 産菜廃裹物処理の法体系}

ここではまず今回の改正の内容をも含めて，産業廃棄 物の処理に関する現行の法体系を概観することとする。 産業廃棄物の処理に関する廃裹物処理法の規定は複雑で あるがその骨子は次のように整理することができよう。

\section{1 事業者処理の原則}

法 3 条 1 項は，「事業者は，その事業活動に伴って生 じた廃棄物を自らの責任において適正に処理しなければ ならない」として事業者の排出者責任の原則を明らかに するとともに，この規定を受けて法 10 条 1 項は，「産業 廃裹物は事業者が自ら処理をしなければならない」とし て事業者の義務を具体化している。ここでいう事業者処 理の原則は，一般廃衰物のように公的なシステムのあと で処理が行われることは原則としてないというにすぎず, いわゆる不法投裹があった場合に排出者に対し民事上ま たは行政法上の責任を追求するにはまた別途検討しなけ ればならないことである。この事業者の処理責任の原則 に対する例外として, 法 10 条 2 項は, いわゆる「あわ せ産廃」に関する市町村の産業廃裹物処理に関する規定 を設けている3)。この規定に基づいて多くの市町村は条 例により市町村が受け入れることのできる産業廃裹物に 関する規定を設けている。しかしこの規定により市町村 があわせ産廃を引き受けざるを得ないとすればその引受 量によっては本来の事務である一般廃棄物の処理に支障 を来すことになる。

さらに産業廃棄物の処分場の設置等についていわゆる 公共関与がしばしば議論され現実にその整備がなされて いるところであるが, この事業者処理責任の原則から いって安易にこれを認めることは問題がある。

\section{2 排出事業者の処理}

\subsection{1 自社処理}

産業廃尧物の排出事業者が自らその産業廃裹物を運搬 又は処分するときは, 政令で定める産業廃裹物の収集,

運搬及び処分に関する基準に従わなければならないもの とされている (法 12 条 1 項)。なお, 特別管理産業廃棄 物についても同様に定められている（法 12 条の 2 第 1 項)。これが事業者の処理責任に基づく基本的な形態で ある゙)。なお，自社処理といわれる産業廃衰物処理には 色々な形態があり, また建設廃棄物では誰が排出事業者 かという問題がある5)。

\section{2 .2 委託による処理}

産業廃裹物の排出事業者は, 他人に収集, 運搬及び処 分を委託することができ，この場合は，政令で定める基 準に従い，産業廃棄物収集運搬業者その他一定の者に委 託することを要し，また処分を委託するときも同様に処 分業者に委託しなければならないものとされている（法 12 条 3 項)。これらの委託契約を行う場合の委託契約の 内容は法施行規則 8 条の 2 の定めるところである ${ }^{6)}$ 。ま た委託契約により産業廃裹物の収集, 運搬及び処分を行 う際には産業廃栽物管理票（マニフェスト）の発行又は 電子情報処理組織の利用が要求される（法 12 条の 3 , 12 条の 4 )。

\section{3 産業廃棄物処理業の許可}

\subsection{1 原則としての許可制度}

産業廃棄物の収集運搬を業として営もうとする者は, その区域を管轄する都道府県知事（保健所市の市長）の 許可を得ることを要する (法 14 条 1 項)。また，産業廃 裹物の処分を営もうとする者についても同様である（12 条 4 項 $)^{7)}$ 。その結果産業廃衰物の排出事業者はこれら 許可を得た者以外に産業廃裹物の収集, 運搬及び処分を 委託することが禁止される (法 12 条 9 項)。この許可要 件は, 厚生省令で定める事業用施設および能力要件が要 求されるほか, 一定の欠格要件がある。この欠格要件は 産業廃裹物の処理に暴力団等が関与する事例が多く見ら れることを反映して次第に厳しくなってきている。

\subsection{2 許可不要の場合}

排出事業者が産業廃裹物を運搬する場合や専ら再生利 用の目的となる産業廃裹物の収集運搬を業として行う者 は許可を要しないとされている ${ }^{8)}$ 。産業廃棄物の処分に ついてあ同様の例外がある。

今回の改正により, 厚生省令で定める産業廃棄物の再 生利用を行い, 又は行おうとする者は, 厚生省令で定め るところにより, 次の各号のいづれにあ適合しているこ とについて，厚生大臣の認定を受けることができるとし， その適合の要件を, $\mathrm{i}$ 当該再生利用の内容が, 生活環境 の保全上支障のないあのとして厚生省令で定める基準に 適合すること, ii 当該再生利用を行い, 又は行おうとす る者が厚生省令で定める基準に適合すること， iii 前号に 規定する者が設置し，又は設置しようとする当該再生利 用の用に供する施設が厚生省令で定める基準に適合する こととされている（法 15 条の 4 の 2 第 1 項)。この制度 によって認定を受けた者は，産業廃争物の収集，運搬又 は又は処分業の許可, 及び産業廃棄物処理施設の設置の 許可を受けることを要しないものとされている（同条 2 項)。 


\subsection{3 特別管理産業廃棄物処理業の許可}

産業廃棄物のうち爆発性, 毒性, 感染性その他の人の 健康又は生活環境に係る被害を生ずるおそれがある性状 を有するすので厚生省令で定められた産業廃棄物（特別 管理産業廃棄物）の収集，運搬処分を業とするものは特 別管理産業廃亊物処理業の許可を受けなければならない (法 14 条の 4 第 1 項, 第 4 項)。

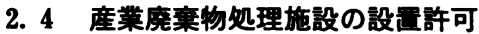

\subsection{1 対象施設}

政令で定める産業廃棄物の処理施設を設置しようとす る者は, 当該産業廃棄物処理施設を設置しようとする地 を管轄する都道府県知事の許可を受けなければならない (法 15 条 1 項)。ここで許可を受けなければならない産 業廃棄物処理施設は, 今回の改正以前では, いわゆる足 切りによって一定の基準以下のミ二施設は許可の対象外 とされていた。今回の改正では中間処理施設について足 切りを縮小し, 最終処分場では足切りを廃止した（施行 令 7 条 5 号, 13 の 2 号, 14 号等)。これは規制対象外処 理施設による環境污染を防止するためその規制強化を図 ることを目的とした改正である。

\section{4 .2 許可基準}

今回の改正以前では, 許可基準は技術上の基準に適合 していること及び産業廃棄物の最終処分場では, 厚生省 令で定めるところにより，災害防止のための計画が定め られているという要件を充足すればよかった。今回の改 正では，新たに許可基準に関する規定を設け，技術上の 基準の他に，その設置に関する計画及び維持管理に関す る計画が当該産業廃棄物処理施設に係る地域の生活環境 の保全について適正な配慮がされていることという要件 が付加された（法 15 条の 2 第 1 項 2 号) $)^{9}$ 。産業廃棄物 の焼却施設など中間処理施設の技術上の基準は，厚生省 令で定められており, また最終処分場に係る技術基準は 総理府・厚生省の共同命令によって定められ, いずれも 今回の法改正により基準が強化された。

\section{4 .3 許可手続}

政令で定める産業廃棄物の処理施設を設置しょうとす る者は, 厚生省令で定める申請書を都道府県知事に提出 しなければならない（法 15 条 2 項）。この申請書を提出 するにあたっては, 生活環境影響調查の結果を記載した 書類を添付しなければならない。この生活環境の調査に 関する内容事項は厚生省令 11 条の 2 に定められている。 都道府県知事は, 諲可申請のあった場合, 遅滞なく申請 者の氏名名称, 設置の場所, 施設の種類, 処理する産業 廃棄物の種類, 縱覧場所等を告示し, 申請書及び生活環 境調查の結果を記載した書類を 1 か月間公衆の縦覧に供
しなければならない（法 15 条 4 項）。都道府県知事は, この告示をしたときは, その旨を関係の市町村長に通知 することを要し，期間を指定して当該市町村長の生活環 境の保全上の見地からの意見を聞かなければならない (法 15 条 5 項)。また告示があったときは, 当該産業廃 棄物処理施設の設置に関し利害関係を有する者は縱覧期 間満了の翌日から二週間を経過する日までに生活環境の 保全上の見地からの意見書を提出することができるすの とされている (法 15 条 6 項)。

この一連の手続は, 今回の改正の重要なポイントであ り, 従来から産業廃棄物処理施設の設置を巡って, 従来 から行われてきた都道府県の要綱による行政指導を回避 し住民との紛争をなくし設置手続を円滑化しようとする ため設けられたものであるが（厚生省の狙いは明らかに これである), 後述するように完全にその目的を達成し ているとはいい難いといえよう。

\section{5 情報公開システム}

行政, 事業者及び国民が，それぞれの役割分担に応じ て環境保全活動を行うには, 環境情報を共有することが 重要である。しかし廃棄物処理の分野では廃棄物処理施 設の設置に関して, どのような廃棄物が排出され又それ が処理され，それによってどのような環境污染をもたら すおそれがあるのかといった面について，付近住民は廃 棄物に関する情報公開を求めるようになっている。廃棄 物処理法は, 都道府県知事が調製した最終処分場に係る 届出台帳について, 関係人から請求があったときは届出 台帳を閲覧させなければならないとする（法 19 条の 5 第 3 項)。この規定について厚生省の解釈では, 埋立終 了後の土地に関して所有権, 地上権等の権利を有する者, それらの権利を取得しようとする者等当該土地について 具体的な権利を有するかまたは有することが予定されて いる者に対して, 埋立終了後の適正な維持管理および利. 用の確保を図るための規定であるとしていた ${ }^{10)}$ 。した がってこの解釈からは，一般住民に対する情報公開シス テムはなかったわけである。

今回の改正は, 前述の産業廃棄物処理施設の設置申請 書及び生活環境にかかる調查の結果を記載した書類の縦 覧制度を設けた。また，政令で定める廃棄物処理施設の 設置者は, 当該施設の維持管理に関し, 厚生省令で定め る事項を記録し，備え置くとともに，当該維持管理に関 し生活環境の保全上利害関係を有する者の求めに応じ閲 覧させるすのとされた（法 15 条の 2 の 3 ) 11)。したがっ て住民に対する情報公開制度ば一歩前進したといえるが， 行政主体が取得している情報については，一般的な情報 公開制度に依存することになるわけである。すなわち地 
方公共団体の情報公開条例がこれを担っているのであ $3^{12)}$ 。

\section{6 監督システムと事後処理措置}

\subsection{1 措置命令}

法 19 条の 4 (改正前の 19 条の 2 ) に定める措置命令 は, 産業廃裹物の不適正な処理に対し, 都道府県知事の 監視体制が弱体であったため，その権限を強化するため に昭和 51 年の廃棄物処理法の改正により導入された制 度である。この措置命令は産業廃裹物の処理基準に適合 しない処理を行った者，及び委託基準に適合しない委託 によって処分を行った場合の委託者に対し，その支障の 除去又は発生の防止のために必要な措置を講ずるべきこ とを命ずるというあのである。しかしその発動の要件が 「生活環境の保全上重大な支障を生じ, 又は生じる恐れ のあるとき」としていたため, その要件の認定について 問題があったので措置命令の発動件数は必ずしも多くな かった。そこで平成 3 年の廃栽物処理法の改正は, この 「重大な」という要件を削除し，発動の要件を緩和した。 今回の改正により措置命令の発動の対象となる者とし て, 産業廃棄物管理票の規定に違反し, 管理票を交付せ ず，又は虚偽の管理票を交付した者もその対象とし（電 子情報組織によるときは虚偽の登録）その適用範囲を拡 充した ${ }^{13)}$ 。

\subsection{2 現状回復措置}

措置命令の制度は違法な産業廃棄物の処理をした者に 対する法制度として有用な制度であるが, 見実には措置 命令を発動しても違法処理をした者に資力がなかったり 不明の場合には措置命令の発動は効果がないか又は発動 ができないことになる。このような場合国又は地方公共 団体の財源によって違法な処分による環境污染の現状回 復を図ることは公平の見地から妥当ではない。そこで今 回の改正では, 都道府県知事が自ら支障の除去措置を行 うことができるとするとともに（法 19 条の 5 )，その費 用の徵収をすることができる旨を規定した。また都道府 県知事が行う支障の除去措置を支援する機構として廃棄 物適正処理推進センターを設置することとした。

\section{3 . 産業廃棄物処理法制の諸問題}

\section{1 今回の廃棄物処理法の趣旨}

今回の改正は, 平成 8 年 9 月に発表された生活環境番 議会産業廃棄物専門委員会が発表した「今後の産業廃棄 物対策の方向について」と題する報告書に基づいている。 この報告書によると, 最終処分場の逼迫や立地困難によ り，不法投裹等が行われ環境污染が生じ，それが住民の
不信を増大させ，建設反対に至ることになる，そこで都 道府県等は地元同意等の要綱を制定し規制することにな り，その結果建設の見込みが不明確になって，最終処分 場の逼迫や立地困難になるという悪循環が存在すると指 摘し、この悪循環を断ち切る必要があるとする。そのた めには, 廃裹物の減量化・リサイクルの推進, 産業廃畗 物に関する信頼性と安全性の向上，不法投棄対策の強化， 不法投棄がされた場合の現状回復システムを構築する必 要があるという。警察の発表では不法投棄等は排出事業 者がコスト削減や始めから储けのために行われている例 が多いというところから, 悪循環のサイクルは必ずしも 全面的に妥当しないと考えられるが（不法投棄をするの は最終処分場がないからではなくコスト削減や始めから 儲けのためであることは警察の資料から明らかである), 今回の改正は, 従来の産業廃衰物処理システムをかなり の部分において変更をおこない一歩前進したことは疑い のないところである。しかし，この改正は産業廃衰物処 理システムを全面的に見直したものではなく，さきに述 べた目的意識から厚生省が必要と考えた改正を施したも のであるだけに中途半端な点があることは拭えなく，ま た新たな疑問を生じさせているといえよう。そこで今回 の改正について幾らかの問題点を指摘する。

\section{2 再生利用の特例制度}

廃棄物処理法は，その制定以来廃棄物の再生利用に関 して廃棄物処理業の許可を要せずに事業活動を行うこと ができるとする例外的制度を認めてきた。すなわち一般 廃棄物の再生利用に関しては, 法 7 条 1 項但書は, 専ら 再生利用の目的となる一般廃衰物のみを収集, 運搬また は処分を業とする者は一般廃棄物処理業の許可の対象と ならないと規定していた。また産業廃裹物については, 法 14 条 1 項但書, 4 項但書に同様の規定を設けていた。 この法 14 条但書にいう「専ら再生利用の目的となる産 業廃率物のみの収集, 運搬又は処分」を行う場合とは, 通達では古紙, くず鉄, あきびん類, 古㵶維のようにそ の物の性質上専ら再生利用される産業廃裹物を取り扱う 場合をいうとしていた。また，平成 3 年 7 日 1 日付厚生 省告示では, 厚生省令 2 条 4 項及び 9 条 4 号にいう広域 的に収集又は運搬することが適当である一般廃棄物及び 産業廃棄物として廃自動車及び廃原動機付自転車が指定 された。さらに, 平成 6 年 6 月 20 日には, 法 6 条の 3 の規定に基づいて廃ゴムタイヤが適正処理困難廃棄物に 指定され，同時に厚生省令 2 条 5 号又は 2 条の 3 第 5 号 により厚生大臣の指定を受けた者が一般廃裹物のみの処 理を行う場合にあっては，一般廃裹物処理業の許可を不 要とするあのであるとされた。 
今回の改正による再生利用の認定の特例制度はこれま で許可の例外的な制度であるとされていた再生利用に関 する法制度にさらに新たな例外制度を設けるものである。 この結果再生利用に関する法制度は複雑化することに なったといえよう。再生利用の認定の特例に関する制度 は，その認定の要件を殆ど法施行規則に委任しており， この規則では施設の設置の要件は産業廃棄物処理施設の 設置に関する要件と同程度の要件が要求されている。こ の認定制度の対象となる産業廃衰物は, 自動車用廃ゴム タイヤ及び泥水式シールド工法又は場所打ち杭工法を用 いた掘削工事に伴って生じた無機性污泥であり, 廃夕イ ヤはセメントの製造に用いられる場合とされ，また無機 性污泥は高規格堤防の盛土に利用することとされている。 しかしこのような特定用途のための制度化が必要である かは, 他の再生利用制度とのバランス上問題がないとは いえない。このような制度をさらに拡充し, 再生利用で きる廃棄物全体の再生利用を促進するためには, 現行の 再生利用に関する法システム全体の見直しとその整備を することが必要であろう。さらにこの再生利用の特例に 関する認定制度は, 法律による行政の原理すなわち行政 と国民間の権利義務を規律するには国会の制定した法律 によるという原則からは, 少なくともその認定の要件自 体は法律で規定する必要があり, この点で今回の再生利 用の認定の特例に関する制度は委任立法の限界からいっ て問題のあるところである。

\section{3 マニフェスト制度}

産業廃衰物の運搬，処分にかかるマニフェスト制度は， 昭和 50 年代から，民間で任意の形で導入されていた。 マニフェスト制度は, 排出事業者からの情報を正確に運 搬, 処分業者に伝えること, 及びそれによって不適正な 処分を防止することを目的とする。このマニフェスト制 度は, 後に厚生省が採用するところとなり, 平成 2 年か らこのマニフェスト制度を産業廃棄物全体について, 厚 生省は, 行政指導として実施してきた（平成 2 年 3 月 26 日付衛環第 18 号通知)。平成 3 年の廃棄物処理法の 改正では，産業廃衰物のうち特別管理産業廃棄物につい て法律上の制度として導入されたのみであった。すなわ ち排出量からみて相当の量に上り不法投棄等問題の生じ ている建設廃棄物については導入が見送られたのである。 このため厚生省は平成 6 年に行政指導として建設廃棄物 についてもその実施を強化したのである（平成 6 年 8 月 3 日付衛環第 82 号通知)。今回の改正ではこのマニフェ スト制度が産業廃棄物の適正な好理に不可欠であるとい う認識から，すべての産業廃棄物について法律上の制度 としたのである ${ }^{14)}$ 。
このマニフェスト制度は, アメリカ連邦法である資源 再生保全法（RCRA）に見習った制度であるといってよ い。しかしアメリカのこの制度は, マニフェストの不交 付や虚偽記載等この制度に違反する者に対する刑事罚が 非常に厳しいのに反し（RCRA 3008 条 d 項, e 項, $\mathrm{t}$ 項), わが国の制度は, マニフェストの虚偽記載には罰 則の適用があるとしても，この制度に関する法令を埒守 しない者に対しては, 都道府県知事は必要な措置を講じ ることを勧告することができる（法 12 条の 3 ） のみで あって, この制度を遵守させることを担保する規定がな いのである。

\section{4 産業廃棄物処理施設の許可露查基準}

前述のように, 今回の改正前の法 15 条 2 項に定める 産業廃棄物処理施設の設置の許可の要件は, 技術基準に 適合すること及び災害に対する計画が策定されているこ とのみであった。そこで産業廃棄物処理施設の設置に よって生活環境の保全上問題のある場合又は住民との紛 争が生じるという場合に, 都道府県は産業廃衰物処理施 設の設置にかかる要綱を制定し付近住民の同意を求め又 は事前協議を行うことを要求するといった行政指導を 行ってきた。しかしこれらは法に定めた要件ではないの であるから, 札幌地裁平成 9 年 2 月 23 日判決（判例自 治 167 号 64 頁）のように住民の同意書又は環境保全協 定が欠けていることをあって不許可処分をすることはで きないという判断がなされることになったのである。

今回の改正では，技術的基準に適合することの他に， 「その設置に係る計画及び維持管理に関する計画が，当 該産業廃裹物処理施設に係る周辺地域の生活環境の保全 について適正な配慮がされたあのであること」という要 件（適正配慮要件）が付加された。また許可申請にあ たっては, 生活環境の影響に関する調查の結果を記載し た書類の添付が要求され, さらに許可にあたっては専門 家の意見の聴取が要求されることになった。しかしこの 生活環境の影響に関する調査の結果を記載した書類の添 付, および専門家の意見の聴取はそれ自体が要件となる のではなく，適正配虑要件の判断資料となるにすぎない のである。都道府県知事は, 許可不許可にあたってこの 資料を谌酌することが要求されているものと解されるが, 適正配慮要件に適合するか否かは法律の定めが抽象的で あるから大幅な裁量を有することになる。したがって結 果として平成 10 年 5 月 7 日付厚生省水道環境部環境整 備課長通知が指摘するとおり, 生活環境の保全に適正な 配慮が行われているかどうかについては, 個々の施設ご との判断にならざるを得ないことになる。

行政手続法 5 条 1 項は, 行政庁は申請により求められ 
た許認可等をするかどうかをその法令の定めにしたがっ て判断するために必要とされる基準を定めるあのとする と規定する。また同法同条 2 項は，行政庁は，番査基準 を定めるに当たっては, 当該許認可の性質に照らしてで きる限り具体的なあのとしなければならないと規定する。 この行政手続法の規定の要求を充して, 全国一律にその 許可基準を定めることは非常に困難であろう。すなわち 生活環境の保全に適正な配慮が行われているかどうかに ついては, 前述のように個々の施設ごとの判断にならざ るを得ないのであるからである。その結果産業廃棄物処 理施設設置の許可が機関委任事務であるとしても都道府 県がその具体的な審査基準を定めなければならないこと になる。

\section{5 生活䍗境調查およひ申請後の諸手続}

今回の改正では, 廃衰物処理施設の設置について, 許 可申請書には生活環境調查の結果を記載した書類を添付 すること, 及び許可申請書等の縦覧, 市町村長の意見書 の提出権並びに生活環境の保全上の利害関係人の意見書 提出権を新たに定めた。この手続をある者はミ二環境影 響評価制度の導入であるというが決して環境影響評価制 度が導入されたわけではない。すなわち調查項目も少な く住民参加の手続あ不十分であるからである。まして地 域の自然的社会的条件から立地の適不適を判断すると いったことは行われないからである。しかしこの一連の 制度は, それまでの許可申請制度と比較すれば一応は進 歩したということができよう。

これまで都道府県は, 産業廃棄物処理施設の許可申請 者と住民との紛争を予防または紛争を調整するため, 要 綱を制定しこの要綱による行政指導によって付近住民の 同意書を要求するといった事例が多かった。また兵庫県, 福岡県等では, 産業廃裹物処理施設の設置に関して住民 との紛争の予防に関する条例を制定してこれに対処して きた。厚生省の見解によれば，今回の廃棄物処理法の改 正により，こうした同意書の要求に代えて前述の手続を 履践することにより円滑に許可手続を進め，したがって 同意書を要求する行政指導は見直されるべきであるとす るのである。

しかし果して新たに設けられたこの一連の手続は, 同 意要綱に代置できるかが問題である。現実には今回の改 正によって, 従来実施してきた同意要綱の見直しを図っ ている都道府県ああろうが, 新聞報道によれば, 多くの 都道府県は指導要綱による規制を継続する方針であると (j ${ }^{15)}$ 。

あとあと産業廃裹物処理施設の設置の許可申請にあ たって, 住民の同意書を取り付けることを求めることは,
許可申請者の任意の協力によってなしうることであり， 許可申請者がこれに服従することを明白に拒否している 場合まであ執拗にこれを求めることはできない（行政手 続法 32 条, 33 条, なお最高裁昭和 60 年 7 月 16 日判 決・民集 39 巻 5 号 989 頁)。それにあかかわらず同意書 を要求するといった実務が実際に行われているのは, 都 道府県の担当者が, 許可申請者と住民の間で任意に利害 調整をすることを期待しているからであろう ${ }^{16)}$ 。そこで 住民が同意書を許可申請者に交付することは住民が生活 環境に関する権利利益を炕分することを意味している。 逆に住民が産業廃棄物処理施設の設置に反対し同意しな いということは自己の権利利益を防衛することを意味す る。

ところが今回の改正により新設された手続は，利害関 係人は意見書を提出するのみで, 許可申請者ないし都道 府県知事は説明会を開催する必要はなく，また許可申請 者は意見書に対する見解を述べる必要あない。したがっ て利害関係人の意見書の提出は情報提供機能しか持って いないことになる。このように同意書の提出と意見書の 提出は異なるものであるから，意見書提出手続があるか らといって都道府県の同意要綱に代置できるわけではな いのである。

\section{6 原告適格は拡充するか}

行政処分の相手方以外の第三者が，行政処分の取消を 求めて出訴する資格があるかについて, 判例は, 行政事 件訴訟法 9 条にいう法律上の利益を有する者とは, 当該 処分により自己の権利若しくは法律上保護された利益を 侵害され又は必然的に侵害されるおそれのある者をいう のであるが，当該処分を定めた行政法規が，不特定多数 の具体的利益を専ら一般的公益のなかに吸収解消させる に止めず，それが州属する個々人の個別的利益としても これを保護すべきすのとする趣旨を含むと解される場合 には，かかる利益も右にいう法律上保護された利益であ るとする ${ }^{17)}$ 。

平成 3 年の改正前の廃棄物処理法による産業廃衰物処 理業の許可取消事件について判例は, 廃棄物処理法は生 活環境の保全と公采衛生の向上という公益の保護を目的 とし，付近住民には許可処分の取消を求めるに付き原告 適格を有しないとする（前橋地裁平成 2 年 1 月 18 日判 決・行裁例集 41 巻 1 号 1 頁)。今回の改正のあとで産業 廃棄物処理施設の設置の許可処分を付近住民が取消を求 めるにつき原告適格があるであろうか。廃棄物処理法 1 条は一般公衆の公益を保護していることについては明ら かである。しかし前述の許可申請書等の縦覧, 市町村長 の意見書の提出権並びに生活環境の保全上の利害関係人 
の意見書提出権に関する規定は，単に公益保護のための 規定ではないことは明らかである。問題になるのは，前 述の利害関係人の意見書提出権は単に情報提供機能を持 つのみであって，「それが帰属する個々人の個別的利益 としてもこれを保護すべきものとする趣旨」という点か らの個々人の権利利益を保護するために設けられた規定 でないのではないかということである。しかし，多くの 場合住民は自分に直接利害関係のない意見を提出すると は考えられず, 利害関係人の意見書提出権は情報提供機 能を持っているとしてもその内容は自己に関係のある情 報であるということができよう。その意味で先の最高裁 の判例の見地に立ったとしても原告適格を有することに なろう ${ }^{18)}$ 。

\section{7 現状回復のあり方}

産業廃衰物が不法投棄されたとき, 又は処分場で処分 されたときでもその方法が不適正であったときは深刻な 環境污染を生じ又は生じるおそれがある。法令にした がって処分されたときであその例外ではないことは，丸 森町事件（仙台地裁平成 4 年 2 月 28 日決定・判時 1429 号 109 頁）の教えるところである。

平成 3 年の廃裹物処理法の改正では, 付則 2 条で不法 投裹に関する現状回復措置を速やかに検討するすのと規 定された。その後平成 7 年 6 月には，厚生省に設置され た不法投棄現状回復方策検討委員会が，不法投棄に対す る行政措置, 民事上の損害賠償及び費用負担のあり方等 について検討が加えられた。

産業廃棄物による環境污染を防止し不法投棄の現状を 回復するための手続および誰がその費用を負担すべきか を解決するには難しい課題が存在する。すなわち平成 8 年 9 月の生活環境審議会産業廃棄物専門委員会の報告書 の作成にあたっても，現状回復にあたって必要な資金を 調達する社会的システムの必要性は認識されていたが, 費用負担のあり方について, 産業廃棄物は産業活動に伴 い生じるあのであることから産業廃裹物の排出を伴う産 業活動を行う者全体で負担すべきである，適正処理を 行ったことが確認されたものを除く排出事業者が負担す べきである，行政す負担すべきである，排出事業者，処 理業者, 行政がそれぞれ負担すべきであるという議論が なされていたということである ${ }^{199}$ 。

今回の改正は，措置命令の適用対象を拡大するととも に，(1) 措置命令を受けた処分者等が，期限までにその 命令に係る措置を講じないとき，講じてあ充分でないと き又は講ずる見込みがないとき，(2) 過失がなくて支障 の除去等の措置を命ずべき処分者等を確知することがで きないときには, 都道府県知事（または一般廃衰物につ
き市町村長）が, 自らその支障の除去等の措置の全部又 は一部を講ずることができるものとした（法 19 条の 5 )。 すなわち不法投裹者不明の場合であ対応することができ るようになったのである。

問題は誰がこれに要する資金を負担するかである。従 来いくらかの都道府県では民間と協力して環境保全対策 基金を設けその費用に充当するといった取組がみられ た ${ }^{20)}$ 。今回の改正では，産業廃棄物適正処理センターを 設置し, 都道府県等が行う 19 条の 5 による生活環境の 支障の除去措置に資金を出捐することその他の協力がで きるあのとした（法 13 条の 13）。この産業廃率物適正 処理センターは, 財団法人産業廃衰物処理事業振興財団 が指定されている。そしてこの資金は事業者等から出捐 される金員で賄われる仕組みになっている（法13 条の 15)。いわば任意の寄附によるシステムである。この基 金は平成 10 年度は 4 億円とされ産業界が 2 分の 1 を負 担し残りは国と地方公共団体が負担するとのことである。 また産業界では建設業界が大半を負担するとのことであ る。

しかしこのような資金のあり方はその量や仕組みに問 題がないであろうか。事業者の任意の寄附による資金シ ステムとしては, かって公害健康被害の補償等に関する 法律（昭和 48 年法第 111 号）の前身である公害に係る 健康被害の救済に係る特別措置法（昭和 44 年法第 90 号）が採用していたところである。しかし任意の寄附に よる制度は事業者の法的責任が不明確であることから事 業者の恩恵によるものと理解されるおそれがあった。そ こでその他の問題点の是正と併せて公害健康被害の補偵 等に関する法律が制定されたという経緯がある。産業廃 菓物の不法投萧に関する今回の制度についてあ建設業界 が不法投裹が多いから寄附を多くしましょうというだけ ではその根拠が必ずしも明確ではなく，公害に係る健康 被害の救済に係る特別措置法と同様の指摘をすることが できよう。さらにその資金量であるが，一旦不法投棄が なされればその現状回復には莫大な資金と労力が必要で あることは豊島事件やいわき市事件 ${ }^{21)}$ の教えるところで ある。今回の改正で予定されているシステムでは直ちに 資金が枯渴することになるおそれがある。

これらの点を是正するには, 排出事業者の排出責任, 資金の負担割合，廃棄物税の導入を含めて強制徽収のあ り方等まだ議論をしなければならない課題がある。

\section{4.残された課題}

\section{1 廃棄物処理行政の複雑化}

明治 33 年に始まるわが国の廃裹物処理行政は公衆衛 
生の向上に始まったといってよい。昭和 45 年の廃㦳物 処理法は, 公衆衛生行政に加えて環境行政の一翼を担う ことになった。その後廃裹物の再資源化・リサイクルが 強調されるにおよび産業行政の面をあ強調されることに なった。一方産業廃裹物の排出量が増大するにつれて産 業廃衰物処理業に関する規制が重要となりこれに対する 営業規制行政が新たな分野として浮かび上がることに なった。また産業行政の面からは, 再生資源の利用の促 進に関する法律 (リサイクル法), 容器包装に係る分別 収集及び再商品化の促進等に関する法律（容器包装リサ イクル法）及び特定家庭用電気機器再商品化法が独立し た。このように現在の廃棄物処理行政は, 昭和 45 年に 廃棄物処理法が制定されて以来何回むの改正を重ね，ま た新しい法律が制定されるに及んで非常に複雑になり所 管する省庁あ多岐にわたっている。

ところでしばしば指摘されているようにわが国の行政 機構は綎割りでありそれぞれの省庁が自己の権益を主張 し省庁間を跨がる行政分野では統一した施策を採用する ことが困難であること，その結果として妥協による立法 が行われるということが通例である。このことは廃棄物 行政の分野であ同じであり，たとえばリサイクル法や容 器包装リサイクル法の制定過程において見られた如くで ある22)。

また都道府県知事は, 産業廃衰物処理行政の遂行過程 では国の事務を担当するとされながら一方では地域の住 民の生活環境の保護を担うという二重の地位に立たされ ている。

平成 6 年 12 月に策定された環境基本計画がいう「污 染者負担の原則を踏まえ，公平な役割分担のもとに環境 負荷の少ない循環型経済社会を構築する」には, 廃棄物 処理行政の分野であ抜本的な改革をしなければならない ところである。そこでここでは残された課題として次の 点を指摘しておきたい。

\section{2 行政改革・地方分権の視点}

戦後のわが国の政治・行政は, 政治が利権の具と化し, 行政もまた自己の守備範囲の死守と権限の拡大を図ると いう図式のもとに運営されてきた。平成 4 年に設置され た行政改革会議以来, 従来の行政運営を見直すため行政 改革による省庁の再編が議題にのぼり, 平成 10 年 6 月 には行政改革を実施するための枠組みを設定するため中 央省庁等改革基本法が制定された。この法律による行政 組織の改革によって国民の期待する改革が実現するか否 かは疑問もないではないが,この行政改革の方向によっ ては廃棄物処理行政も大きな影響を受けることになる。 すなわち同法 24 条は, 廃裹物処理法に係る対策は, 環
境省に一元化するとし，また資源の循環的利用の促進は 関係省庁の共同の所管とすると規定している。これは従 来厚生省の所管であった廃棄物行政が環境保全行政と一 元化することを意味する。これまで廃棄物処理行政は省 庁間の権限の争奪により実際に制度化された法システム は多くは妥協の産物であったから，この点の一元化は廃 率物処理行政にとって大きな進歩であろう。たとえば従 来環境庁が有していた各種の基準の定立と厚生省が有し ていたその実施システムが統一的に行われることになる ことを考えるとその点はすぐ理解できよう。しかし廃棄 物の発生の抑制を図るべき商品の生産・流通の面は別の 省庁（経齐産業省等）に委ねられることになると考えら れこの点の先は見えていない。この点の解決を図り廃異 物・リサイクルを一体とした望ましい物質循環を促進す る新たな法体系を樹立するためには, 内閣機能の強化に よって政策調整機能を発揮することが要求される。

つぎに廃棄物行政にとって重要な点は国と地方公共団 体の役割分担の関係である。これまで廃衰物処理法はそ の改正を重ねるごとに国の権限が拡大され，一方では地 方公共団体がその具体的な実施を担うといったことが行 われてきた。いわゆる機関委任事務の拡大である。平成 7 年に制定された地方分権推進法の 2 条は「地方分権の 推進は，国と地方公共団体が共通の目的である国民福祉 の増進に向かって相互に協力する関係であることを踏ま えつつ, 各般の行政を展開する上で国及び地方公共団体 が分担すべき役割を明確にし，地方公共団体の自主性及 び自立性を高め, 個性豊かで活力に満ちた地域社会の実 現を図ることを基本とする」としている。そしてこの法 律により設置された地方分権推進委員会の第 1 次勧告で は，機関委任事務を廃止を提言するとともに，地方公共 団体の事務を自治事務と法定受託事務とすることとした。 また, この第 4 次勧告では, 廃裹物処理法の今回の改正 にも言及し，「現在の機関委任事務制度の下で全国各地 で起こっている混乱は, 単に法定受託事務か自治事務か の事務区分の整理で解決される問題ではない。国の責任 の下で廃棄物の適正処理と施設の円滑な設置を可能とす る仕組みの構築に向けて, 国は問題解決の前線に立ち率 先して解決処理にあたるなど，国の役割や責任の強化を 内容とする抜本的な制度改正が遠からず不可避であるよ うに思われる。とする。そして差しあたりの暫定的な 整理として, 産業廃棄物に関する殆どの事務を法定受託 事務と位置づけているのである。

これだけの改革をなし遂げるには，なお多くの議論と 労力が必要なことは確かである。しかし最も重要なこと は改革に向けての政治的原動力であろう。さらのこの改 革および廃棄物行政の抜本的改正に向けての視点は, 単 
に省庁間の改革を横系とし国と地方公共団体の役割分担 の再編を縦系として国が事務的に改革を推進するという 視点ではなく, 国と地方公共団体の関係の役割分担の再 編が広い意味での行政改革の内容であって, 省庁間の再 編はその外枠を決めるあのであるという視点であろう。 いい換えれば地方公共団体がどれだけのことができるか という自己の存在を発揮することシステムを作ることが まず重要であるといえるのである。

\section{3 廃棄物処理法からの改革の視点}

廃棄物処理法によれば, 廃棄物とは「ごみ, 粗大ごみ, 燃えがら, 污でい, ふん尿, 廃油, 廃酸, 廃アルカリ, 動物の死体そのたの污物又は不要物であって固形状又は 液状のものをいう」とする（法 2 条 1 項）。污物は客観 的にみて社会通念上不要物であるが, 廃棄物処理法は新 たに不要物という概念を導入している。すなわち廃棄者 の主観的な意思により廃棄物となるわけである。しかし 厚生省の解釈によると, 廃裹物とは, 占有者が自ら利用 し，または他人に有償で売却することができないために 不要となったものをいうとしている。したがって有価性 のある物は廃棄物ではないわけである。このように廃棄 物の概念のなかには三つの要素がある。

このように廃裹物の概念のなかに法文上必ずしも明ら かでない有価性概念を導入した結果，ある物が廃棄物で あったりそうでなかったりする場合があることになる。 すなわち有偵で引取ってあらうときは廃裹物でなく無償 の場合または逆有偵の場合は廃衰物であることになる ${ }^{23)} 。$

廃裹物処理法は, このような必ずしあ明確でない廃棄 物概念を中心に据えその法体系を構築している。まず第 一に，廃裹物を処理する業者は許可が必要であり廃棄物 を取り扱っていないとなれば許可は必要でない。すなわ ち廃裹物概念は許可システムの根幹概念であることにな る。また廃裹物概念を前提として廃棄物処理法はその再 生利用という制度を設けているところ，再生利用に関し ては許可不要の場合が存在していることは前述のとおり である。このような複雑な体系からは必然的に脱法行為 が発生することになる。さらに産業界からはある物が廃 累物であるとされるとその収集，運搬及び処分につき許 可が要求され，一方で再生利用されるものかどうかはそ れ相応の判断を必要とするところから廃棄物の適用を除 外してほしいという要求が出ることになる。第二に，廃 裹物の意義をどのように理解するにせよ，廃棄物概念を 中心とすることは結果として適正処理という面が表面に 出てくることになりその結果技術優先的法律になってく る。実際のところ廃衰物処理法は, 廃棄物の減量化, 再 資源化，再利用を規律する規定は少なくまたそれあ訓示
的規定や強制力のない規定に終始している（法 3 条, 4 条, 6 条の 3,12 条 5 項など)。

今日のように廃裹物の質が変化しその量も増大してい る時代では，廃棄物の適正処理という下流対策のみでは すでにその限界が来ているといってよい。今回の改正法 の国会番議において，采議院が循環型経済社会の実現に 向けて，廃棄物の排出抑制，リサイクルの促進を含めた， 製造業者，排出事業者，行政，住民がそれぞれ責任を持 ち一体となっての総合的な廃棄物対策を一層充実するこ と，と付帯決議しているが，この決議を実現するには， 資源の採取，その生産・加工・流通および消費といった 過程を物質循環のサイクルを構築するための新たな法制 度が必要である。その際の要求されるのは適正処理とい うことに繫がりやすい廃棄物概念を見直し，物質循環の サイクルで発生した排出物を環境負荷を生じないように 処理すべき物と資源としてこのサイクルに再投入すべき 物とに分類するといった発想であろう。

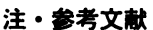

1）廃衰物処理法の制定過程については, 瀬田公和他：逐 条解説廃衰物処理法, ぎょうせい（1972）

2）この改正の概要については，村田哲夫：改正廃棄物処 理法の考え方, 月刊廃尧物, 2 月号, 日報, pp. 199203 (1992)

3） あわせ産廃の処理ができることを条例で規定している 例として, 福岡市廃衰物の減量及び適正処理に関する 条例 24 条, 25 条, 26 条。

4) 自社処理による不法投棄等の問題点については, 北村 喜宣：産業廃衰物への法政策対応, 第一法規, pp. 127 142 (1998)

5 ）東京高裁平成 5 年 10 月 28 日判決, 判時 1483 号 17 頁。

6）しばしば産廃業者が安価な料金で産業廃棄物の収集運 搬及び処分を受託し，それが不法投菓の原因になると の指摘から，今回の厚生省令の改正で委託契約中に料 金が記載されることになった。

7 ）この産業廃棄物処理業の許可は蜀束裁量であると考え られる。また付近住民は，許可処分を争うにつき原告 適格を有しない（前橋地裁平成 2 年 1 月 18 日判決, 行 裁例集 41 巻 1 号 1 頁)。

8）厚生省の解説によると, 専ら再生利用の目的となる廃 裹物とは，古紙，くず鉄，あきびん類，古織維である とする, 厚生省水道環境部編 : 廃衰物処理法の解説, p. A 281 (1996)

9）今回の改正前の廃棄物処理法による許可について効果 裁量が認められ不許可処分ができるとする説につき， 北村喜宣：産業廃棄物設置許可における知事の裁量, 平成 9 年度重要判例解説, 別冊ジュリスト, 1135 号, 有斐閣, p. 47 (1998) 今回の改正では，要件の認定に知事に大幅な裁量権が あり不許可処分が可能であると考えられる。 
10）厚生省水道環境部編：前掲書, p. A 400 （1996）

11）現実に住民がこの制度を利用できるかについては，疑 問なしとしない。けだし誠実な業者はこれに応じると 考えられるが, 問題のある業者は事実を隠蔽したり実 力で住民の請求を排除することが予想されるからであ る。

12）廃衰物と情報公開については, 曽和俊文: 産業廃衰物 処理行政と情報公開, ジュリスト, 1120 号, 有斐閣, pp. $59-65$ (1997)

村田哲夫 : 廃衰物問題と情報公開, 環境法研究, 24 号, 有斐閣, pp. 16-30（1997）

13）措置命令については, 北村喜宣：前掲書, pp. 55-65 (1998)

14）マンフェスト問題取材班：現行マニフェストシステム の経緯と課題, いんだすと, 2 月号, pp. 17-19 (1997)

15）日本経済新聞平成 10 年 5 月 28 日朝刊。

16） あまりこのことを強調すると, 行政に期待されている 調整機能を放棄することになりかねない。

17）最高裁平成元年 2 月 17 日判决, 民集 43 巻, 2 号, 56 頁
（新潟空港事件）。

18）鼎談，住民同意を考える，北村喜宣発言参照，いんだ すと，7月号，(1998）

19）生活環境審議会廃衰物処理部会産業廃衰物専門委員 会：今後の産業廃栽物対策の基本的方向について (1996)

20）森 達也：環境保全対策基金の設置状況，いんだすと， 10 月号, pp. 30-35 (1996)

21）いわき市事件の経過については, 鈴木淳一：廃油等不 法投棄事件の現状回復における問題点と新たな制度の 創設について, いんだすと, 10 月号, pp. 36-40 (1996)

22）容器包装リサイクル法の成立過程についてはたとえば, 村上.朝子：ドキュメント容器包装廃裹物新法成立, リ サイクル文化 50 号, pp. 23-39 (1995)

大塚 直 : 容器包装リサイクル法の特色と課題, ジュリ スト, 1074 号, pp. 110-116 (1997)

23）この点の批判については, 阿部泰隆 : 廃栽物処理法の 改正と残された課題 1 , 自治研究 69 巻 6 号, 良書普及 会, pp. 3-23 (1994)

\title{
The Present State of Waste Management Law and its Problem to be Solved
}

\author{
Tetsuo Murata \\ Professor, Osaka-gakuin University \\ ( 2-36-1, Kishibeminami, Suita-city, 564-0115 Japan)
}

\begin{abstract}
In 1970, the Law Concerning Waste Disposal and Public Cleanliness was enacted in Japan.

This law was the most innovative to date in the field of the waste management administration. This law declared that business enterprises are responsible for the disposal of industrial wastes.

But, the amount of industrial wastes has increased year by year, and the securing of final disposal sites has become more difficult. As a result, illegal dumping and other forms of improper treatment of wastes are often seen, and these produce a conflict between citizens fearing influences upon their health and dumpers/haulers.

The 1997 Amendment of the foresaid Law aims to dissolve these problems and to improve the industrial wastes disposal, system. This Amendment includes the reformation of the license system to construct disposal facilities, the adoption of manifest system for all industrial wastes and others.

But, this Amendment can not be considered a complete reformation of the legal system. There still remain plenty of problems.

For future reformation of the industrial wastes management system, it is important to take in to account two points of view. One is administrative reformation and decentralization of government, and the other is the reexamination of the meaning of wastes.
\end{abstract}

Key words : illegal dumping, 1997 amendment of the Law administrative reform, decentralization of government, meaning of wastes 